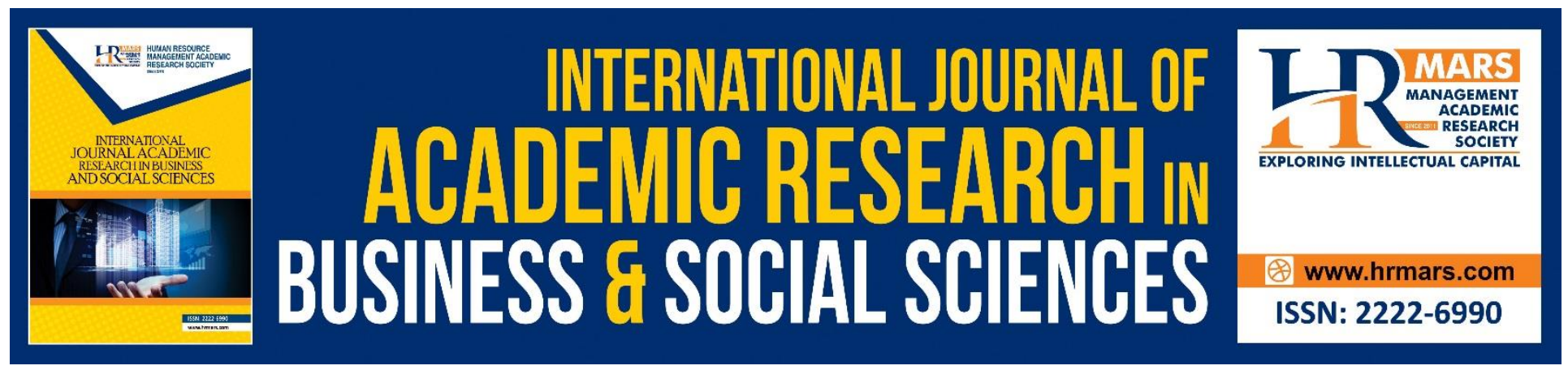

\title{
The English Language Needs of the Armed Forces Officers Using Task Based Language Teaching
}

\author{
Surjeet Singh, Belinda Marie Balraj
}

To Link this Article: http://dx.doi.org/10.6007/IJARBSS/v9-i1/5861

DOI: $10.6007 /$ IJARBSS/v9-i1/5861

Received: 12 Dec 2018, Revised: 11 Jan 2019, Accepted: 04 Feb 2019

Published Online: 27 Feb 2019

In-Text Citation: (Singh \& Balraj, 2019)

To Cite this Article: Singh, S., \& Balraj, B. M. (2019). The English Language Needs of the Armed Forces Officers Using Task Based Language Teaching. International Journal of Academic Research Business and Social Sciences, 9(1), 1299-1308

Copyright: (C) 2019 The Author(s)

Published by Human Resource Management Academic Research Society (www.hrmars.com)

This article is published under the Creative Commons Attribution (CC BY 4.0) license. Anyone may reproduce, distribute, translate and create derivative works of this article (for both commercial and non-commercial purposes), subject to full attribution to the original publication and authors. The full terms of this license may be seen

at: http://creativecommons.org/licences/by/4.0/legalcode

Vol. 9, No. 1, 2019, Pg. 1299 - 1308

Full Terms \& Conditions of access and use can be found at http://hrmars.com/index.php/pages/detail/publication-ethics 


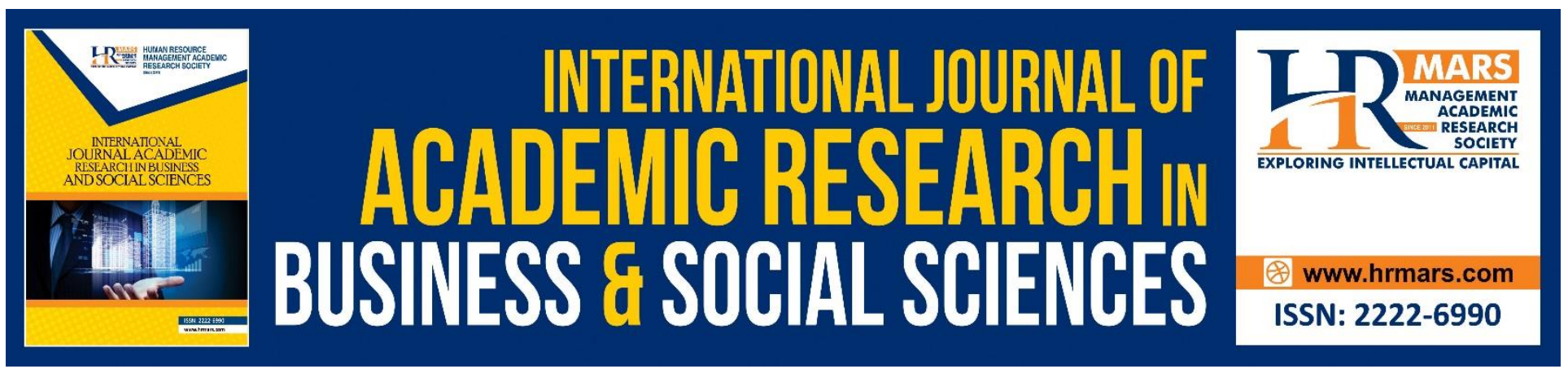

\title{
The English Language Needs of the Armed Forces Officers Using Task Based Language Teaching
}

\author{
Surjeet Singh, Belinda Marie Balraj \\ National Defense University of Malaysia, Malaysia
}

\begin{abstract}
The Malaysian Armed Forces (MAF), comprising the Army, the Navy and the Air Force, and entrusted with the important responsibility of national security, is also expected to project a positive image of Malaysia in the international arena as it (the MAF) engages in peace-keeping and relief operations with joint forces from various other countries. Like almost every other institution in the world, it has been impacted by globalisation, and is thus constantly engaging in efforts to upgrade itself in all aspects, especially those related to equipping itself with the necessary knowledge and expertise required to meet the demand for better services to the country and the people. The paper looks at the status quo of the English language in relation to the three Services (Army, Navy and Air Force), and the role played by the English language in the career development of an Armed Forces officer using Task Based Language Teaching focussing on Acquisition-Learning hypothesis and the Affective Filter hypothesis. The findings show that all four language skills, namely, listening, speaking, reading and writing are important to the MAF officers.
\end{abstract}

Keywords: Malaysian Armed Forces, Second Language Acquisition, Language Needs, Career Development, Task Based Language Teaching

\section{Introduction}

It is a well-known fact that almost every institution and organization in the world has been impacted by globalization, which brings with it several phenomena, such as increased competition and incessant efforts to increase the effectiveness and efficiency of products and services. These have in turn created a number of forces that have come to be labeled as the K-factors (where $\mathrm{K}$ stands for knowledge-based), and include phenomena such as the K-Revolution, the K-Economy, and the subject of this study, the K-Force. And since these forces are dependent on effective communication and demand the use of a common language, English, the undisputed lingua franca of international communication for business and technology, has fitted comfortably into this role.

The Malaysian Armed Forces (MAF), comprising the Army, the Royal Malaysian Navy (RMN) and the Royal Malaysian Air Force (RMAF), are no exception to this trend, and are thus constantly engaging 
INTERNATIONAL JOURNAL OF ACADEMIC RESEARCH IN BUSINESS AND SOCIAL SCIENCES Vol. 9, No. 1, Jan, 2019, E-ISSN: 2222-6990 @ 2019 HRMARS

in efforts to upgrade themselves in all aspects, especially those related to equipping themselves with the necessary knowledge and expertise required to meet the demand for better services to the country and the people. Their efforts to increase efficiency and efficacy are built on the twin concepts of Revolution in Military Affairs (RMA) and the K-Force, and realized through the concept of the MAF as a learning organization.

The RMA has contributed significantly to the advancement of military doctrine and the modernization of the MAF, and changed the paradigm for the need of advanced technological hardware. It gives emphasis to quick reaction, knowledge of the warfare zone and pin-point accuracy of weapons. According to the explanation given by the Australian Defense Studies Centre in the Australian Defense Force Journal, ADFJ (No. 44, Sept - Oct 2000: 1) "a military revolution typically occurs when the application of the new technologies into a significant number of military systems combines with innovative operational concept and organizational adaptation in a way that dramatically increases military effectiveness and fundamentally alters the character and conduct of military operations."

A crucial issue here is that in order to fully utilize the potential of the RMA, it is necessary to have a sound understanding of military literature, which is mainly in English. The K-Force stands for the creation of a knowledge-enabled Armed Force, where its soldiers and officers have relevant knowledge and ICT skills, and are receptive to technological and global changes (ADFJ: 9). Like for the RMA, in order for them to be so enabled, they should have a good command of the English language. In order to achieve the tenets of the K-Force, the MAF needs to have the right kind of labor in place. Soldiers have to be equipped with the right skills and training. Ways of thinking have to change as the MAF seeks to acquire the technology and knowledge that would make it a continuously relevant force well into the $21^{\text {st }}$ century.

These are the days where the enemy is fought beyond the horizon and where every bit of information and step of an operation or movement is digitalized. Malaysia has to move with the times and absorb the new technology and the system that comes with both the RMA and the K-Force. In fact, the view of the then Deputy Prime Minister who was also the Defense Minister, Dato Seri Najib Tun Razak, was that Malaysia cannot be out of sync with what is happening around the world, and the MAF will have to come to terms with this and transform themselves. The RMA and the K-Force are themselves a conglomeration of various observations on how different technologies have succeeded in multiplying force capability many times over, thus unleashing the potential for further developments.

An organization, which wants to keep on improving in the new millennium, will have to always strive for success, pioneer new knowledge, develop the capacity for learning and become a catalyst of change. In order to do this, the organization has to engineer a new concept of learning and provide high-quality facilities to its members. The MAF attempts to do this by sending their officers to various institutions locally and abroad, and upgrading existing learning facilities. Two local Malaysian military institutions where officers attend a one-year course are the Malaysian Armed Forces Defense College (MAFDC, also called the Defense College), and the Malaysian Armed Forces Staff College (MAFSC, also called the Staff College), The courses that the MAF officers need are conducted in English, 
regardless of whether these are held here or abroad. It is, thus, essential that the course participants have a good command of the English language.

Another reason for giving importance to the staffs' mastery of the English language is that this language is very important when joint operations are carried out during the United Nations (UN) peacekeeping activities and during joint military exercises between and among countries. In order to ensure maximum understanding and cooperation, all orders are given in English and a standard military register for language is used. This is especially important for officers as they are the prime strategists in any warfare. One very important aspect that needs to be borne in mind is that the Armed Forces have their own language register: the structures and lexis of this register (for example, wardroom, RV, tarmac and bombardier) have special meanings that are used and understood only by military personnel. Thus the type of English that these personnel are required to master falls somewhere along the EGP-ESP continuum, and in order to help them learn it, it is necessary that a needs analysis be carried out to identify their lacks, needs and wants vis-à-vis the English language.

\section{Task-Based Language Teaching}

Task-based teaching was made famous by Ellis (2005) when he presented a paper at Pusan, Korea, on the 10 Principles of Instructed Learning. Prior to this, various other names have been used, such as project-based, content-based, theme-based and text-based syllabuses (Nunan, 2006). Despite their differences, they all have one thing in common, that is, they do not rely on prior analysis of the language into discrete points (which was the basis for the syntactic approaches). Task based language teaching, then, grew out of this alternative approach to language pedagogy.

Since then, the concept of 'task' has become an important element in syllabus design, classroom teaching and learner assessment and it has influenced educational policy-making in both ESL and EFL settings. Pedagogically, task-based language teaching has strengthened the following principles and practices (Nunan, 2006).

-A needs-based approach to content selection

-An emphasis on learning to communicate through interaction in the target language

- The introduction of authentic texts into the learning situation

-The provision of opportunities for learners to focus, not only on language, but also on the learning process itself

-An enhancement of the learner's own personal experiences as important contributing elements to classroom learning

-The linking of classroom language learning with language use outside of the classroom

Tasks have been defined in various ways. Nunan (2004) draws a basic distinction between real-world or target tasks, and pedagogical tasks. Target tasks, as the name implies, refer to uses of language in the world beyond the classroom. Pedagogical tasks are those that occur in the classroom. 
Another definition of a pedagogical task is as stated by Breen (1987:23) "any structured language learning endeavor which has a particular objective, appropriate content, a specified working procedure, and a range of outcomes for those who undertake that task. 'Task' is therefore assumed to refer to a range of work plans which have the overall purposes of facilitating language learning from the simple and brief exercise type, to more complex and lengthy activities such as a group problem-solving or simulations and decision-making."

Ellis (2003:16) defines task in the following way,

"A task is a work plan that requires learners to process language pragmatically in order to achieve an outcome that can be evaluated in terms of whether the correct or appropriate propositional content has been conveyed."

To this end, it requires them to give primary attention to meaning and make use of their own linguistic resources, although the design of the task may predispose them to choose particular forms. A task is intended to result in language use that bears resemblance, direct or indirect, to the way language is used in the real world. Like other language activities, a task can engage productive and receptive, and oral or written skills and various cognitive processes.

\section{Principles of Instructed Learning}

Ellis's principles of instructed learning have been used as a convenient summary of principles that help provide appropriate conditions for SLA. These act as a kind of checklist for unit design that is independent of the rationale of the task-based approach.

- Instruction needs to ensure that learners develop a rich repertoire of formulaic expressions and a rule-based (linguistic) competence.

-Instruction needs to ensure that learners focus predominantly on meaning.

- Instruction needs to ensure that learners also focus on form.

- Instruction needs to be predominantly directed at developing implicit knowledge of the L2 but should not neglect explicit knowledge.

-Instruction needs to take account of the learners' built-in syllabizing.

- Successful instructed language learning requires extensive L2 input.

- Successful instructed language learning also requires opportunities for output.

- The opportunity to interact in the L2 is central to developing L2 proficiency.

- Instruction needs to take account of individual differences in learners.

-When assessing learners' L2 proficiency, it is important to examine free as well as controlled production.

It is the purpose of this study, therefore, to investigate and describe the English language needs of the MAF in relation to the K-Force with a focus on task based learning in designing an effective language learning programme for the staff so that the vision of both the MAF and the nation can be achieved. 
INTERNATIONAL JOURNAL OF ACADEMIC RESEARCH IN BUSINESS AND SOCIAL SCIENCES

Vol. 9, No. 1, Jan, 2019, E-ISSN: 2222-6990 @ 2019 HRMARS

\section{Methodology}

Research Subject: The study specifically covers the English language needs of MAF officers attending the one-year courses at the Staff and Defence Colleges that include the Diploma Course at University Malaya (for the Staff College course) and the Masters course at Universiti Kebangsaan Malaysia (for the Defence College Course).

This study has focused on only one group of tri-service students who attended the Staff College course (Course 35/2006) and the Defence College course (Course 26/2006).

Procedures: A qualitative approach to research involves the researcher being in contact with participants in their natural settings to answer questions related to how the participants make sense of their lives. As the study also involved ethnography which specifically seeks understanding of what participants do to create the culture in which they live, and how the culture develops over time, participant-observation was preferred.

In second language acquisition (SLA) research, observations are more often used to collect data on how learners use language in a variety of settings, to study language learning and teaching processes in the classroom, and to study teachers' and students' behavior in and outside classrooms.

Data Collection: As a participant-observer, the researcher sat behind in the lecture hall during central discussions, attended 'a model room discussion' and joined a field exercise when a field appreciation was being presented. (An 'appreciation' is a military term used to evaluate a situation (pro's and con's) before a decision is made as to the appropriate action to be taken by the Commander in the reaction towards enemy forces.) The researcher also socialized with the students and staff in the Officers' Mess to gauge their impromptu use of the English language.

\begin{tabular}{|c|l|}
\hline Observations & $\begin{array}{l}\text { No. of } \\
\text { hours }\end{array}$ \\
\hline $\begin{array}{l}\text { 1. } \\
\text { 2. } \begin{array}{l}\text { Syndicate } \\
\text { Presentations }\end{array}\end{array}$ & 6 hours \\
6 hours \\
3. $\begin{array}{l}\text { Practical } \\
\text { Exercises }\end{array}$ & 2 hours \\
4. $\begin{array}{l}\text { Field Visit to } \\
\text { Asahan } \\
\text { 5. Syndicate } \\
\text { Discussions }\end{array}$ & 8 hours \\
\hline
\end{tabular}


INTERNATIONAL JOURNAL OF ACADEMIC RESEARCH IN BUSINESS AND SOCIAL SCIENCES

Vol. 9, No. 1, Jan, 2019, E-ISSN: 2222-6990 ㄷ 2019 HRMARS

\section{Results}

The following results will discuss the data gathered during the researcher's observation in the selected designations.

\section{Listening}

It was highlighted by the students that listening skills (English) were important to the officers as they must listen to lectures and presentations, and be able to use telephone sets while carrying out military exercises. The Malaysian officers can cope quite well in these activities but have problems if the speaker is a foreigner with a foreigner accent. The overseas students had problems initially while adjusting to the Malaysian accent but got used to it as the courses progressed. However, among the 'losses' sustained due to poor listening skills in rank order were

a) Difficulty in understanding instructions.

b) Difficulty in taking down notes

c) Instructions/ Orders were not very well Understood

d) Tendency to misinterpret and, therefore, giving Wrong opinions

\section{Reading}

Most of the officers from both the colleges had problems with the reading skill, especially when it came to the Masters and the Diploma programs, as they had difficulty absorbing the academic literature. They did not have this problem when it came to the military modules, as the language used here was part of their 'register', but had problems when it came to subjects such as Strategic studies, International Relations and National and Regional Affairs. As such, they had the following problems:

a) They lacked sufficient background knowledge

b) They were limited to Bahasa Malaysia references

c) It affected their research as they had difficulty in assimilating reference material in English

d) They were unable to cope with high-powered texts

e) They lacked understanding and it affected their confidence

f) It led to time wastage for the officers

\section{Speaking}

The interviews showed that oral communication played a very important part during the courses at the MAFSC and MAFDC. This is because the officers are continuously being assessed not only on their written assignments but also on their 'observed participation' during discussions, question sessions and oral presentations. (Assessment Validation Report Instruction). This method of assessment is used to gauge students' intellect, verbal communication ability and interactive ability to share their thoughts and experiences during discussions, presentations and exercises.

All the three services had problems that were similar when it came to the various skills. Since the RMAF and the RMN tended to use more English during working hours, officers from these services 
had fewer problems as compared to Army officers, especially those from the Royal Malay Regiment (RMR). This was probably because the RMR Officers had little exposure to English. $80 \%$ of the officers agreed that their lack of ability to use the various skills diminished their chances for:
a) Promotion
b) Postings abroad
c) Holding Command and Staff appointments
d) Taking part in the United Nations Peacekeeping
Force
e) Attending courses abroad

\section{Writing}

The officers from both colleges felt that when reading skills were poor, it affected their writing skills, too. This was highlighted by the students when they gave feedback that they had a lot of difficulty in writing their research papers as it involved not only looking for reference material but also extracting relevant information and putting it into writing in a clear, logical and sequential manner. Thus the 'losses suffered' in rank order were:
a) Not being able to produce good assignments
b) Not being able to express thoughts in writing
c) Not being able to write in a brief and concise Manner
d) Difficulty in writing the research paper
e) Difficulty answering exam questions during the Diploma course

\section{Discussion}

According to the information obtained in this study, $23 \%$ of the officers had the English Language as their medium of instruction in schools, whilst $77 \%$ had Bahasa Malaysia (BM). Furthermore, based on the information related to the mother tongue of the respondents in Table 5.4, BM dominates with 94.2\% (English is $2.2 \%$, Chinese, $1.4 \%$ and Tamil, $2.2 \%$ ). From these data, it can be concluded that BM is the dominant language of the respondents, especially at home and in the society. However, the medium of instruction in both the MAFSC and MAFDC is the English language. This is because English is the second language used in Malaysia, and Malaysian students have at least 11 years of schooling where the English language is taught. So, English is also given due importance and recognition in the working environment of the MAF.

Due to the nature of work, which involves duties both in the Military Unit as well as outside, English plays an important role in this institution. Although initially an officer may be using more BM in the working environment, which may suffice for the day-to-day administration, he needs English for many other purposes. For instance, the English language becomes indispensable when an officer has to deal with other government agencies, the private sector, foreign embassies and foreign military organisations. This use of the English language will further increase as the officer rises the ranks and 
is posted to higher formations such as the Brigade, the Division, the Headquarters Formations and the Ministry of Defence (MINDEF). In these higher formations, English is the main medium of communication, as the officers must deal with foreign military organisations.

Another important area where MAF officers need English is when the language becomes the lingua franca during joint operations with neighbouring countries such as Thailand, the Philippines, Indonesia and Singapore, each of which have their own national languages. Since the medium of instruction for both the military colleges (MAFSC and MAFDC) is English, it is evident that a good command of the language will be a catalyst in the successful completion of the course. Students must do a lot of reading where the references are in English, and later write academic papers, which are all in English. Even their university courses are in English. Furthermore, the presence of foreign students whose medium of communication is English makes it critical that the Malaysian students be proficient in the language so that there can be effective socialisation and intermingling among them.

\section{Conclusion}

There were various types of feedback given regarding the type of English course that is suitable for the students. $70 \%$ of the students from the Staff College and $50 \%$ from the Defence College said that what they needed was a skill-based course emphasising the four skills of speaking, listening, reading and writing. However, from the interviews with the lecturers and the Directing Staff (DS), it was stated that many of the Staff College students were poor in their grammatical skills, and needed a course on grammar. Apparently, the students in the Defence College had a better grasp of the grammar of the English language. What they needed were better communication, thinking, and negotiation skills. This was because the main objectives of the Defence College course were to ensure that the course participants can evaluate the concepts and factors that were relevant to the provisions of policy advice on national security, military strategy, the employment of joined and combined military forces as well as the command and control of such forces at the strategic and operational levels of war.

It can be seen, therefore, that a two-week pre-sessional English course concentrating mainly on grammar and the four skills should be planned for all Staff College students (Appendix I). This will serve as an introduction to them, and at the same time give them an idea of the level of English used at the Staff College and UKM courses. Furthermore, during their first month of the Staff College course, they should have English classes which focus on Communication and Thinking Skills (CATS). This is where topics such as speed reading, skimming, scanning, interpreting argumentative texts and oral presentations should be emphasised. Another area that should be given emphasis is academic writing to prepare them for the writing of their dissertations. They should be guided in producing a good dissertation by teaching them how to write the various sections of such a document, such as the introductory parts, the literature review, the methodology, the findings and discussion, and the concluding parts.

For the Defence College, the pre-sessional course on grammar is not needed because, as stated earlier, most of the course participants have a reasonably good command of the grammar of the English language due to their seniority in service. However, what they are lacking are skills related to 
negotiation, delivering a presentation confidently and writing dissertations for the Master's programme. Most of them have had exposure to these skills in the Staff College course, but there is a need to upgrade these to meet the objectives of the Defence College course. It was pointed out by the Defence College Commandant that these officers need these skills and have to be good in English because officers in the higher rank are sometimes required to attend courses and seminars overseas. Also, they are subject to international deployment when they get involved in joint military exercises and UN peace-keeping activities. Thus, what they need are also speed-reading skills, interpreting argumentative texts at a higher level and writing research dissertations for their Master's programme.

Basically, the skills needed for the Staff College and Defence College students are quite similar as both groups undergo military courses that emphasise military literature, academic literature and international relations. As pointed out earlier, what the students lack most or have difficulty in are reading and writing skills which are applicable at tertiary education levels. The only difference between both groups of students is that Staff College students need an extra course on grammar.

Task Based Learning is relevant for the military personal as whatever they have studied must be put into practical. The military personals have various manuals regarding weapons, servicing equipment's as well as repairing the equipment on the ground. Thus, whatever learned must be put into practise while doing the job. The military personals must also be able to comprehend the manuals brought from overseas and in English. Therefore, it is pertinent for them to understand English or ESP to conduct their daily chores. This is the relevancy of Task Based Learning as it has to be put into practice on ground.

\section{Corresponding Author}

Surjeet Singh

National Defence University of Malaysia,Malaysia

surjeet@upnm.edu.my

\section{References}

Breen, M. P. (1987). Learner contributions to task design. In C. Candlin and D. Murphy (Eds.)

Language learning tasks. Englewood Cliffs NJ: Prentice Hall.

Ellis, R. (2003). Task-based language teaching. Oxford: Oxford University Press.

Ellis, R. (2005). Principles of instructed language learning. In P. Robertson, P. Dash and J. Jing (Eds). English language learning in the Asian contect. (pp. 12-26). Pusan: The Asian EFL Journal Press.

Defence International Training Centre. 2002. Australian Defence Force English Language Profiling System (ADFELPS): Information Book. Laverton: DITC.

Nunan, D. (2006). Task-based language teaching in the Asian context: Defining 'task'. Asian EFL Journal (Sept 2006). 